\title{
Pseudomonas syringae pv. coryli, the Causal Agent of Bacterial Twig Dieback of Corylus avellana
}

\author{
Marco Scortichini, Maria Pia Rossi, Stefania Loreti, Adriana Bosco, Mario Fiori, Robert W. Jackson, \\ David E. Stead, Andy Aspin, Ugo Marchesi, Maurizio Zini, and Jaap D. Janse
}

\begin{abstract}
First and second authors: C.R.A.-Istituto Sperimentale per la Frutticoltura, Via di Fioranello, 52, 00040 Ciampino, Roma, Italy; third and fourth authors: C.R.A.-Istituto Sperimentale per la Patologia Vegetale, Via C.G. Bertero, 22, 00156 Roma, Italy; fifth author: Dipartimento di Protezione delle Piante, Università degli Studi di Sassari, Via E. De Nicola, 07100 Sassari, Italy; sixth author: Department of Plant Sciences, University of Oxford, South Park Road, OX1 3RB Oxford, U.K.; seventh and eighth authors: Central Science Laboratory, Sand Hutton, Yo41 1LZ York, U.K.; ninth and tenth authors: Dipartimento di Virologia e Biotecnologie, Istituto Zooprofilattico Sperimentale delle Regioni Lazio e Toscana, Via Appia Nuova, 1411, 00178 Roma, Italy; and eleventh author: Department of Bacteriology, Plant Protection Service, 6700 HC, Wageningen, The Netherlands.
\end{abstract}

Current address of R. W. Jackson: Department of Biology and Biochemistry, University of Bath, Claverton Down, BA2 7AY Bath, U.K. Accepted for publication 13 July 2005.

\begin{abstract}
Scortichini, M., Rossi, M. P., Loreti, S., Bosco, A., Fiori, M., Jackson, R. W., Stead, D. E., Aspin, A., Marchesi, U., Zini, M., and Janse, J. D. 2005. Pseudomonas syringae pv. coryli, the causal agent of bacterial twig dieback of Corylus avellana. Phytopathology 95:1316-1324.

Thirty-eight bacterial strains isolated from hazelnut (Corylus avellana) cv. Tonda Gentile delle Langhe showing a twig dieback in Piedmont and Sardinia, Italy, were studied by a polyphasic approach. All strains were assessed by fatty acids analysis and repetitive sequence-based polymerase chain reaction (PCR) fingerprinting using BOX and ERIC primer sets. Representative strains also were assessed by sequencing the 16S rDNA and $h r p L$ genes, determining the presence of the $\operatorname{syr} B$ gene, testing their biochemical and nutritional characteristics, and determining their pathogenicity to hazelnut and other plants species or plant organs. Moreover,

they were compared with reference strains of other phytopathogenic pseudomonads. The strains from hazelnut belong to Pseudomonas syringae (sensu latu), LOPAT group Ia. Both fatty acids and repetitivesequence-based PCR clearly discriminate such strains from other Pseudomonas spp., including $P$. avellanae and other $P$. syringae pathovars as well as $P$. syringae pv. syringae strains from hazelnut. Also, the sequencing of $16 \mathrm{~S}$ rDNA and $h r p L$ genes differentiated them from $P$. avellanae and from $P$. syringae pv. syringae. They did not possess the syrB gene. Some nutritional tests also differentiated them from related $P$. syringae pathovars. Upon artificial inoculation, these strains incited severe twig diebacks only on hazelnut. Our results justify the creation of a new pathovar because the strains from hazelnut constitute a homogeneous group and a discrete phenon. The name of $P$. syringae pv. coryli is proposed and criteria for routine identification are presented.
\end{abstract}

Hazelnut (Corylus avellana L.), also known as filbert, cob nut or European hazelnut, is a widespread tree commonly found in Europe in natural stands from Scandinavia to southern Europe. Commercial orchards are present mainly in Turkey, Italy, the United States, Spain, Iran, and France, although specialized cultivations also occur in Poland, United Kingdom, The Netherlands, Croatia, Greece, and Portugal. A severe decline of the tree caused by Pseudomonas avellanae (9) has been reported in commercial orchards of northern Greece and central Italy (province of Viterbo) $(23,29)$. The main symptom of decline is the sudden wilting of the whole tree occurring from spring to autumn; longitudinal cankers on trunks and branches also are found occasionally.

Strains belonging to $P$. syringae pv. syringae sensu lato have been associated with a partial wilting of the twigs and branches in some areas of hazelnut cultivation in Italy such as Sardinia, Latium, Campania, and Sicily (31). Furthermore, another group of strains from hazelnut, not possessing the $s y r B$ gene coding for the production of syringomycin, showed phenotypic and molecular features different from the previous strains (32). These isolates first were found associated with a twig dieback of the hazelnut cv. Tonda Gentile delle Langhe, in Piedmont in northwestern Italy

Corresponding author: M. Scortichini; E-mail address: mscortichini@yahoo.it

DOI: 10.1094/PHYTO-95-1316

(C) 2005 The American Phytopathological Society
(30) and, subsequently, with twig dieback, cankers, and wilting of cv. Tonda Gentile delle Langhe trees cultivated in Sardinia (4).

In this article, we describe the identification and characterization of the causal agent of twig dieback isolated from hazelnut cv. Tonda Gentile delle Langhe in Piedmont and Sardinia. A comprehensive polyphasic examination of the strains was done by analysis of $16 \mathrm{~S}$ rDNA and $h r p L$ genes sequences, repetitivesequence polymerase chain reaction (PCR), fatty acid analysis, presence of $s y r B$ gene, biochemical and nutritional tests, and pathogenicity and host range tests. Our work provides conclusive evidence that the causal agent is distinct from $P$. avellanae and from other pathogenic varieties of $P$. syringae and we propose a new pathovar, $P$. syringae pv. coryli.

\section{MATERIALS AND METHODS}

Bacterial strains. In all, 38 strains obtained from hazelnut cv. Tonda Gentile delle Langhe in Piedmont $(30,31)$ and Sardinia (4) were selected as representative for the study and compared with other phytopathogenic pseudomonads (Table 1). All strains were cultured on nutrient agar (NA; Oxoid, Basingstoke, UK) or on NA supplemented with $5 \%$ of sucrose (NSA) at 25 to $27^{\circ} \mathrm{C}$.

Cell and colony morphology. The cell morphology of representative bacterial twig dieback strains from hazelnut (ISPaVe 592 and DPP 51) was studied with a Zeiss TEM 100 electron microscope (Zeiss, Jena, Germany) following the technique described by Schaad (28), and the measurements of 20 cells/strain were made. Colony morphology was studied on NA and on NSA. 
Biochemical and nutritional tests and ice nucleation activity. Biochemical and nutritional tests were performed according to Lelliott and Stead (14). Ice nucleation activity was checked at -5 and $-10^{\circ} \mathrm{C}$ with a refrigerated circulating bath (Endocal RTE 210; Neslab, Newington, $\mathrm{NH}$ ), following the technique described by Lindow (15). Assimilation of selected organic compounds by the strains was performed using API 20 NE strips (BioMérieux, Marcy-l'Etoile, France). In addition, the assimilation of 49 carbon sources by the type-strain of the new pathovar and by some other phytopathogenic pseudomonads was carried out using API $50 \mathrm{CH}$ strips (Bio Mérieux).

$16 S$ rDNA sequencing. The entire 16S rDNA gene was sequenced for three strains of the new pathovar, ISPaVe 592 (NCPPB 4273), 595, and 598, as well as for P. avellanae BPIC 714 isolated in Greece and ISF 2059 isolated in central Italy. A loopful of pure culture of each strain, grown on NSA at 25 to $27^{\circ} \mathrm{C}$, was suspended in $0.5 \mathrm{ml}$ of sterile reagent grade water (Millipore Corp., Billerica, MS) and placed in boiling water for 10 min to obtain a lysed cell suspension for use as PCR template. To amplify the $16 \mathrm{~S}$ rDNA, the primers P0 (5'-GAGAGTTTGATCCTGGCTCAG-3') and P6 (5'-CTACGGCTACCTTGTTACGA-3') (5) were used. The PCR mixture was prepared in a final volume of $50 \mu \mathrm{l}$ containing $5 \mu \mathrm{l}$ of template, 2.5 units of Platinum Pfx DNA polymerase (Invitrogen, Carlsbad, CA), 1× Pfx amplification buffer, $1.5 \mathrm{mM} \mathrm{MgSO}$, 30 pmol of each primer, and $300 \mu \mathrm{M}$ each dNTP and run on a Gene Amp PCR System 2400 (Applied Biosystems, Foster City, CA) thermal cycler with cycling conditions of $95^{\circ} \mathrm{C}$ for $2 \mathrm{~min}$ ( 1 cycle), followed by 30 cycles each comprising melting at $95^{\circ} \mathrm{C}(30 \mathrm{~s})$, annealing at $55^{\circ} \mathrm{C}$ (30 s), and extension at $68^{\circ} \mathrm{C}(4 \mathrm{~min})$. The amplicon was purified using a PCR purification kit (Qiagen, Hilden, Germany) according to the manufacturer's instructions, and visually quantified by comparing with standard concentrations of DNA molecular weight marker VI (Roche Diagnostics, Basel, Switzerland). For each strain, the amplicon was progressively sequenced using primers P0 and P6 with Big Dye Terminator (Applied Biosystems) and primer walking to complete coverage of the DNA fragment. On a Gene Amp PCR System 2400 thermal cycler, a final volume of $20 \mu \mathrm{l}$, comprising $20 \mathrm{ng}$ of purified amplicon, 2.4 pmol of primer, and $8 \mu \mathrm{l}$ of Big Dye terminator Cycle Sequencing Ready reaction Mix (Applied Biosystems), was incubated at $96^{\circ} \mathrm{C}$ for $2 \mathrm{~min}$ and subjected to 25 cycles at $96^{\circ} \mathrm{C}(10 \mathrm{~s})$, $50^{\circ} \mathrm{C}(5 \mathrm{~s})$, and $60^{\circ} \mathrm{C}(4 \mathrm{~min})$. Excess Big Dye terminators were removed by Centri-sep-spin columns (Princeton Separations Inc., Adelphia, NJ) according to the manufacturer's instructions. All the sequences were analyzed on an ABI PRISM 310 Genetic Analyzer (Applied Biosystems) provided with Genetic Analysis Data Collection software (version 1.2.2) and Sequencing Analysis Software (version 3.4.1).

Partial 16S rDNA sequencing. To compare a larger number of strains of the new pathovar with some pseudomonads showing similarity in some genomic features (17), sequencing of a $16 \mathrm{~S}$ rDNA variable region (448 nucleotides in the gene position 409 to 856) (22) also was performed. Strains of the new pathovar, ISPaVe 592 (NCPPB 4273), 593, 595, 598 (isolated in Piedmont), DPP 48, and 51 (isolated in Sardinia) were compared with the 16S rDNA partial sequences of $P$. avellanae NCPPB 3873 (ISPaVe 011) and P. syringae pv. phaseolicola 1448A. Bacterial total DNA was extracted using a Puregene extraction kit (Flowgene, Saint Beauzire, France). Total DNA (20 ng) was used in $25 \mu \mathrm{l}$ of PCR mixture comprising each primer (16S-F and $16 \mathrm{~S}-$ $\mathrm{R})(22)$ at $1 \mathrm{pmol} / \mu \mathrm{l}$ and $0.4 \mathrm{mM}$ deoxynucleotide triphosphates. SuperTaqPlus and buffer (HT Biotechnology) were used according to the manufacturer's instructions. The PCR conditions were $94^{\circ} \mathrm{C}$ for $10 \mathrm{~min}(1 \mathrm{cycle})$ followed by 30 cycles of $94^{\circ} \mathrm{C}(30 \mathrm{~s})$, $62^{\circ} \mathrm{C}(30 \mathrm{~s})$, and $68^{\circ} \mathrm{C}(1 \mathrm{~min})$, with a final extension step of $68^{\circ} \mathrm{C}$ (10 min). A 5- $\mu$ l aliquot of the post-PCR mixture was checked on a $1.5 \%$ agarose gel and the remaining $20 \mu \mathrm{l}$ of mix was cleaned up using a QIAPREP-PCR clean-up kit (Qiagen). Sequencing of both strands of the 16S rDNA fragment was done using $200 \mathrm{ng}$ of the cleaned PCR fragment, the PCR amplification primers at $1.0 \mathrm{pmol} / \mu \mathrm{l}$, and BigDye 3.1 termination mix according to the manufacturer's instructions. The exception to this was the partial sequencing of the $16 \mathrm{~S}$ rDNA genes of strains ISPaVe 592 (NCPPB 4273) and 593. The genes were cloned into the plasmid pCR2.1 using the Original TA cloning kit (Invitrogen, Paisley, UK) according to the manufacturer's instructions. Sequencing of both strands of the $16 \mathrm{~S}$ fragment was done after cultivation of positive transformants and plasmid miniprep (QIAPREP) (Qiagen) using the same conditions used for sequencing PCR fragments.

Sequencing of the $\operatorname{hrpL}$ gene. The full-length $h r p L$ gene and an internal 290-bp region were amplified and sequenced. The strains assessed for the full-length hrpL gene were ISPaVe 592 (NCPPB 4273), ISPaVe 598, DPP 51, P. avellanae NCPPB 3873 (ISPaVe 011), and BPIC Fl13. Bacterial genomic DNA was purified as described by Ausubel et al. (1). Primers L7 (ATTTTCATAGGACGATTCTG) and L8 (GGAGAACTGGATATACGCAT) were used to amplify the full hrpL gene; primers L1 (ACCTGGTTGTGTGGCATTGC) and L2 (CCGTGAGCGGACGGTGCC) were used to amplify an internal $h r p L$ region (2). The PCR reaction was carried out in a 50- $\mu \mathrm{l}$ reaction mixture containing $25 \mathrm{ng}$ of genomic DNA, $0.2 \mathrm{mM}$ dNTPs, $0.1 \mu \mathrm{M}$ each primer, and $1 \times$ PCR buffer (MBI Fermentas, Lithuania). Pfu DNA polymerase (2.5 units per reaction) (MBI Fermentas) was added to the PCR reaction at $70^{\circ} \mathrm{C}$ for $3 \mathrm{~min}$ (hot start). The thermal profile consisted of an initial denaturation step at $94^{\circ} \mathrm{C}$ for 2 min followed by 35 cycles at $94^{\circ} \mathrm{C}(1 \mathrm{~min}), 55^{\circ} \mathrm{C}(1 \mathrm{~min}), 72^{\circ} \mathrm{C}(2 \mathrm{~min})$, and a final elongation step of $72^{\circ} \mathrm{C}$ for $10 \mathrm{~min}$ for $h r p L 7$ and 8 ; and 30 cycles at $94^{\circ} \mathrm{C}(30 \mathrm{~s}), 60^{\circ} \mathrm{C}(30 \mathrm{~s}), 72^{\circ} \mathrm{C}(1 \mathrm{~min})$, and a final elongation step of $72^{\circ} \mathrm{C}$ for $7 \mathrm{~min}$ for $h r p L 1$ and 2 . All the amplicons $(5 \mu \mathrm{l})$ were analyzed on $1 \%(\mathrm{wt} / \mathrm{vol})$ agarose gel cast and run in TBE buffer (0.09 $\mathrm{M}$ Tris-borate and $0.002 \mathrm{M}$ EDTA). The remaining $45 \mu \mathrm{l}$ of the amplicon was purified using a Nucleospin extract kit (Macherey Nagel, Düren, Germany). Sequencing of both strands of the $h r p L$ gene was carried out by M-Medical (Pomezia, Italy). The full length of $h r p L$ sequences of two P. syringae pv. phaseolicola (AC: AB016381 and U16817), $P$. syringae pv. tomato (AC: $\mathrm{AB} 016421)$, and $P$. syringae $\mathrm{pv}$. syringae (AC: U03854) strains, taken from the GenBank database, were included in the analyses.

Sequence analysis. Sequences were aligned using the multiple alignment Clustal algorithm (7). Phylogenetic and molecular analysis were conducted using MEGA version 2.1 (12) and computed using Kimura's two-parameter model (10) and the neighborjoining (NJ) clustering algorithm (25). Bootstrap analyses were performed to estimate the significance level of the NJ tree internal branches (6).

Repetitive-sequence-based PCR genomic fingerprinting. Genomic fingerprints were determined for each strain as described by Louws et al. (18) using primers corresponding to prokaryotic enterobacterial repetitive intergenic consensus (ERIC) and to the BOXA subunit of the BOX element (BOX) (Eurogentec, Belgium). The fingerprints were compared with those of other phytopathogenic pseudomonads (Table 1). Bacterial DNA preparations were obtained as described by Scortichini et al. (31). Amplification was performed on an MJ Research (Watertown, MS) PTC 100 programmable thermal cycler. Each $25-\mu$ reaction mixture contained each deoxynucleoside triphosphate $(200 \mu \mathrm{M})$, $2 \mathrm{mM} \mathrm{MgCl}_{2}, 60 \mathrm{pmol}$ of each primer, $1.0 \mathrm{U}$ of Taq polymerase (Promega Corp., Madison, WI), and $3 \mu$ of bacterial DNA preparation. The PCR mixture was overlaid with $25 \mu$ of mineral oil. The thermal cycling procedure was that used by Louws et al. (18). Subsequently, the PCR amplification products were separated by gel electrophoresis on a $6 \%$ acrylamide gel in $1 \times$ TBE buffer at $160 \mathrm{~V}, 4^{\circ} \mathrm{C}$, for $30 \mathrm{~min}$ in a BioRad MiniProtean apparatus (BioRad, Hercules, CA). Gels were stained with ethidium bro- 
mide, visualized with a Spectroline UV transilluminator (Spectronic Corporation, Westburg, NY), and photographed with Polaroid type 55 film. The PCR amplifications were performed in duplicate and the method of Smith et al. (33) was used for the analysis. The clearly resolved bands present in both amplifications gels were scored and recorded. Similarity coefficients for all pairwise combinations were determined by using Dice's coefficient (3) and were clustered by unweighted pair group method with arithmetic means (UPGMA) using the NTSYSpc software (version 2.11j; Exeter Software, NY) (24). Phenograms were constructed with the tree display option (TREE).

Fatty acid methyl esters analysis. Thirty-three strains of the new pathovar and other phytopathogenic pseudomonads were compared by fatty acid methyl esters (FAME) analysis. Bacteria were grown for $48 \mathrm{~h}$ at $28^{\circ} \mathrm{C}$ on trypticase soy agar, composed of trypticase soy broth supplemented with $1.5 \%$ Bacto agar. Cells (40 mg wet weight) were harvested from the most dilute quadrant showing confluent growth (cells in late log phase). Whole-cell fatty acids were analyzed as described by Janse (8) and Stead (35) using the Microbial Identification System (MIS; Microbial ID, Inc. [MIDI], Newark, NJ). The FAME profiles of the strains were compared with those of other phytopathogenic pseudomonads held in the FAME Databanks maintained at the Plant Protection Service, Wageningen, The Netherlands and at the Central Science Laboratory, Sand Hutton, York, United Kingdom.

Presence of $\operatorname{syr} \boldsymbol{B}$ gene. The presence of the $s y r B$ gene was determined for all strains of the new pathovar by using the procedure of Sorensen et al. (34). Primers B1 (5'-CTTTCCGTGGTC-

TABLE 1. Pseudomonas strains used in this study ${ }^{\mathrm{a}}$

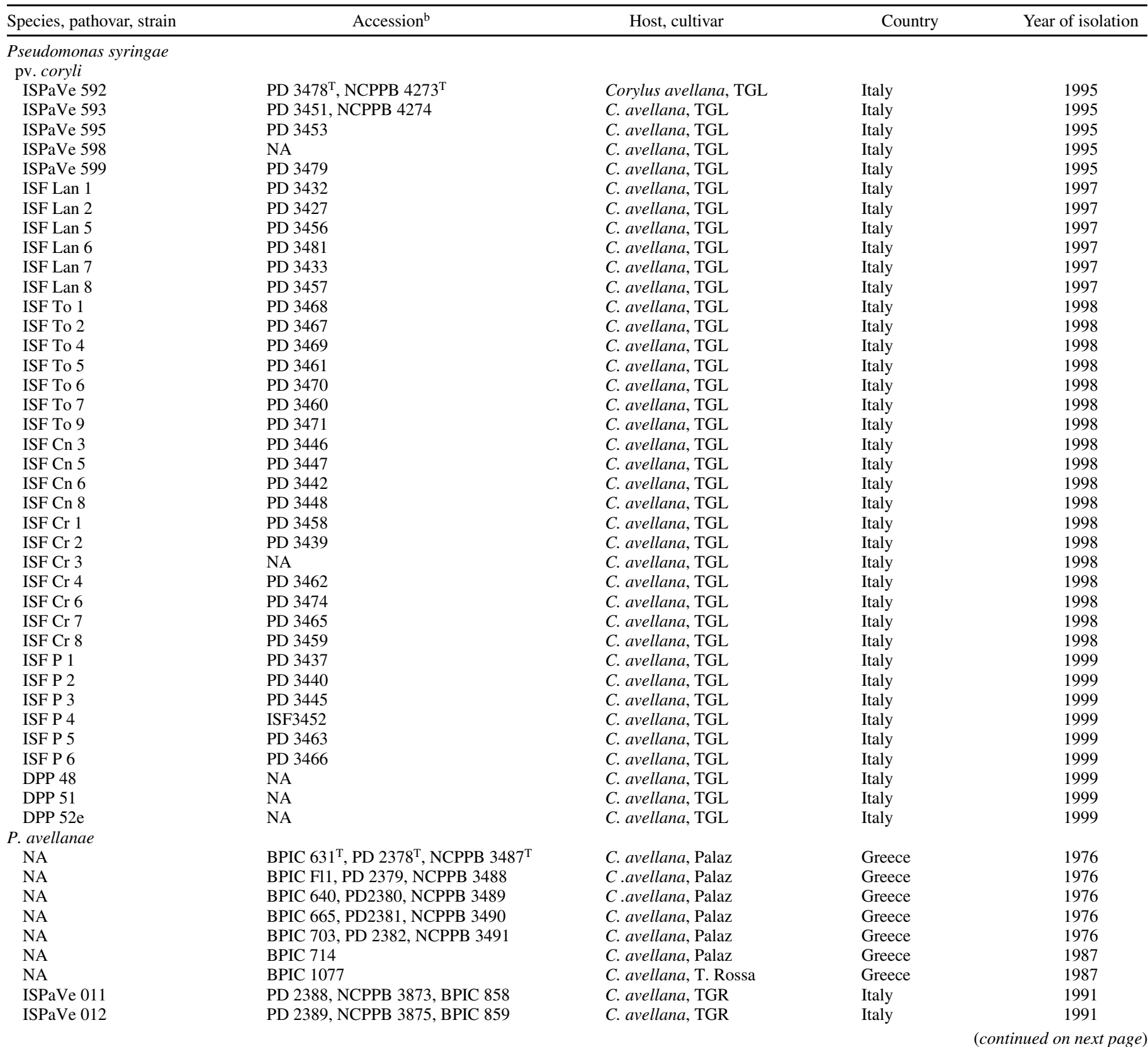

${ }^{\text {a }}$ Abbreviations: ${ }^{\mathrm{T}}=$ type strain, TGL $=$ Tonda Gentile delle Langhe, and NA = unknown or not assigned.

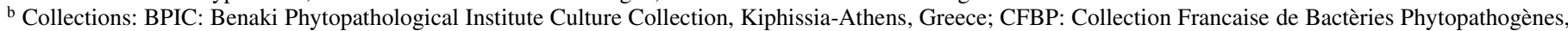
Angers, France; DPP: Culture Collection of Dipartimento Protezione delle Piante, Università di Sassari, Sassari, Italy; ISF: Culture Collection of Istituto Sperimentale per la Frutticoltura, Roma, Italy; ISPaVe: Culture Collection of Istituto Sperimentale per la Patologia Vegetale, Roma, Italy; KACC: Korean Agricolture Culture Collection, Chonnam, South Korea; NCPPB: National Collection of Plant Pathogenic Bacteria, CSL, Sand Hutton, York, United Kingdom; and PD: Culture Collection of Plant Protection Service, Wageningen, The Netherlands. 
TTGATGAGG-3') and B2 (5'-TCGATTTTGCCGTGATGAGTC$3^{\prime}$ ) were synthesized by Eurogentec (Seraing, Belgium).

Pathogenicity and host range tests. All strains were tested for their ability to elicit a hypersensitivity reaction by infiltration into tobacco leaves. For the pathogenicity and host range tests, nine representative strains of the new pathovar were used: ISPaVe 592 (NCPPB 4273), 593, ISF Cn1, Lan2, To4, and Cr3, isolated in Piedmont, and DPP48, 51, and 52e, isolated in Sardinia. The following plant species were inoculated: hazelnut (Corylus avellana L.) cvs. Tonda Gentile delle Langhe and Tonda Gentile Romana, apple (Malus $\times$ domestica Borkh.), pear (Pyrus communis L.), apricot (Prunus armeniaca L.), peach (P. persica Batsch.), lilac (Syringa vulgaris L.), tomato (Lycopersicon esculentum Mill.), and pepper (Capsicum annuum L.). For inoculation of hazelnut, apple, pear apricot, peach, and lilac, each strain was tested in three 2-year-old, pot-cultivated plants and, on each plant, four lateral, 1-year-old twigs were chosen. Hazelnut plants were inoculated either in autumn or spring. In autumn (early October), inoculations were performed by placing $10 \mu \mathrm{l}$ of bacterial suspension $\left(10^{7} \mathrm{CFU} / \mathrm{ml}\right)$ in the leaf scar immediately after leaf removal. In spring, (early May), the young shoots were gently wounded with a sterile scalpel and drops of the suspensions were placed on the wounds. Control plants were wounded in the same way and treated with sterile phosphate buffer. After inoculation, plants were covered with plastic bags for $48 \mathrm{~h}$ and, subsequently, kept in open air for further observation. Reisolations were performed after symptoms appeared using techniques described elsewhere $(4,30)$. The other woody plant species were wounded on

TABLE 1. (Continued from preceding page)

\begin{tabular}{|c|c|c|c|c|}
\hline Species, pathovar, strain & Accession $^{\mathrm{b}}$ & Host, cultivar & Country & Year of isolation \\
\hline ISPaVe 013 & PD 2390, BPIC 860 & C. avellana, TGR & Italy & 1992 \\
\hline ISPaVe 038 & PD 2383 & C. avellana, TGR & Italy & 1993 \\
\hline ISPaVe 039 & PD 2384 & C. avellana, TGR & Italy & 1993 \\
\hline ISPaVe 040 & PD 2385 & C. avellana, TGR & Italy & 1993 \\
\hline ISPaVe 041 & PD 2386 & C. avellana, TGR & Italy & 1992 \\
\hline ISPaVe 037 & PD 2392 & C. avellana, TGR & Italy & 1992 \\
\hline ISF 112 & PD 3428 & C. avellana, TGR & Italy & 1997 \\
\hline ISF Rad3 & PD 3430 & C. avellana, TGR & Italy & 1998 \\
\hline ISF SVT7 & PD 3431 & C. avellana, TGR & Italy & 1998 \\
\hline ISPaVe 036 & PD 3434 & C. avellana, TGR & Italy & 1993 \\
\hline ISF SL & PD 3435 & C. avellana, TGR & Italy & 1998 \\
\hline ISF SVT9 & PD 3449 & C. avellana, wild tree & Italy & 1998 \\
\hline ISF Rad9 & PD 3450 & C. avellana, TGR & Italy & 1998 \\
\hline ISPaVe 056 & PD 3473 & C. avellana, TGR & Italy & 1994 \\
\hline ISPaVe 042 & PD 3475 & C. avellana, TGR & Italy & 1992 \\
\hline ISF 2059 & PD 3476 & C. avellana, TGR & Italy & 1994 \\
\hline ISF 691 & PD 3477 & C. avellana, TGR & Italy & 1996 \\
\hline ISF SCR2 & PD 3482 & C. avellana, wild tree & Italy & 1998 \\
\hline ISF SCR3 & PD 3483 & C. avellana, wild tree & Italy & 1998 \\
\hline \multicolumn{5}{|l|}{ P. syringae } \\
\hline \multicolumn{5}{|l|}{ pv. syringae } \\
\hline $\mathrm{NA}$ & NCPPB $281^{\mathrm{T}}$ & Syringa vulgaris & United Kingdom & 1950 \\
\hline NA & NCPPB 1087 & Prunus avium & Hungary & 1958 \\
\hline NA & NCPPB 1092 & P. armeniaca & New Zealand & 1951 \\
\hline NA & NCPPB 1093 & P. armeniaca & New Zealand & 1951 \\
\hline ISPaVe 015 & NCPPB 3869 & Laurus nobilis & Italy & 1992 \\
\hline ISF SarA1 & NA & C. avellana & Italy & 1998 \\
\hline ISF SarB6 & NA & C. avellana & Italy & 1998 \\
\hline ISF Sic1 & NA & C. avellana & Italy & 1999 \\
\hline ISF Sic4 & NA & C. avellana & Italy & 1999 \\
\hline pv. theae (NA) & NCPPB $2958^{\mathrm{T}}$ & Thea sinensis & Japan & 1970 \\
\hline pv. theae (NA) & CFBP 4096 & Camellia sinensis & Japan & 1970 \\
\hline pv. theae (NA) & CFBP 4097 & Camellia sinensis & Japan & NA \\
\hline \multicolumn{5}{|l|}{ pv. actinidiae } \\
\hline NA & NCPPB $3739^{\mathrm{T}}$ & Actinidia deliciosa & Japan & 1984 \\
\hline NA & NCPPB 3740 & A. deliciosa & Japan & 1984 \\
\hline NA & NCPPB 3871 & A. deliciosa & Italy & 1992 \\
\hline NA & NCPPB 3873 & A. deliciosa & Italy & 1992 \\
\hline NA & KACC 10592 & A. deliciosa & South Korea & 1999 \\
\hline NA & KACC 10754 & A. deliciosa & South Korea & 1997 \\
\hline pv. persicae (NA) & NCPPB $2761^{\mathrm{T}}$ & Prunus persica & France & 1974 \\
\hline pv. pisi (NA) & NCPPB $2585^{\mathrm{T}}$ & Pisum sativum & New Zealand & 1969 \\
\hline \multicolumn{5}{|l|}{ pv. phaseolicola } \\
\hline $1448 \mathrm{~A}$ & NA & Phaseolus vulgaris & Ethiopia & 1985 \\
\hline NA & $\mathrm{NCPPB} 52^{\mathrm{T}}$ & P. vulgaris & Canada & 1941 \\
\hline pv. tomato (NA) & NCPPB $1106^{\mathrm{T}}$ & Lycopersicon esculentum & United Kingdom & 1960 \\
\hline pv. ulmi (NA) & NCPPB $632^{\mathrm{T}}$ & Ulmus sp. & ex Yugoslavia & 1958 \\
\hline pv. eriobotryae (NA) & NCPPB $2331^{\mathrm{T}}$ & Eriobotrya japonica & United States & 1970 \\
\hline pv. morsprunorum (NA) & NCPPB 2787 & Prunus avium & Greece & 1961 \\
\hline pv. helianthi (NA) & NCPPB $2640^{\mathrm{T}}$ & Helianthus annus & Ethiopia & 1961 \\
\hline pv. tagetis (NA) & NCPPB $2488^{\mathrm{T}}$ & Tagetus erecta & Zimbabwe & 1972 \\
\hline pv. lachrymans (NA) & NCPPB $537^{\mathrm{T}}$ & Cucumis sativus & United States & 1935 \\
\hline pv. porri (NA) & NCPPB $3364^{\mathrm{T}}$ & Allium porrum & France & 1978 \\
\hline pv. garcae (NA) & NCPPB $588^{\mathrm{T}}$ & Coffea arabica & Brazil & 1958 \\
\hline$P$. viridiflava (NA) & NCPPB $635^{\mathrm{T}}$ & Phaseolus sp. & Switzerland & 1927 \\
\hline$P$. viridflava (NA) & BPIC 394 & Solanum melongena & Greece & 1972 \\
\hline P. amygdali (NA) & NCPPB $2607^{\mathrm{T}}$ & Prunus amygdalus & Greece & 1967 \\
\hline
\end{tabular}


the shoots and inoculated in spring as described for hazelnut. Control plants were wounded in the same way and treated with sterile phosphate buffer. In addition, lemon fruit and bean pods also were inoculated with the same strains. Young leaves of tomato and pepper plants were inoculated by gently wounding the lower surface of the leaf with a sterile syringe; subsequently, 10 to $20 \mu \mathrm{l}$ of the suspension were placed on the wound. Lemon (Citrus lemon Osbeck) fruit and bean (Phaseolus vulgaris L.) pods were surface sterilized with $0.5 \%$ sodium hypochloride, rinsed with sterile distilled water, and inoculated by wounding the epidermis with a sterile syringe and placing 10 to $20 \mu \mathrm{l}$ of the bacterial suspension at the same dose as above. After inoculations, the fruit and pods were placed in a humid chamber for $48 \mathrm{~h}$ at room temperature for $16 \mathrm{~h}$ of light and $8 \mathrm{~h}$ of dark. Lemon fruit inoculated with $P$. syringae pv. syringae NCPPB 3869 were used as positive control. Finally, fruit and pods treated with sterile distilled water also were used as negative control.

\section{RESULTS}

Cell and colony morphology. Cells of bacteria isolated in Piedmont and Sardinia from the hazelnut cv. Tonda Gentile delle Langhe were gram-negative rods with rounded ends and one to three polar flagella. Cell measurements indicated a mean length of $1.5 \mu \mathrm{m}$ and a mean width of $0.6 \mu \mathrm{m}$. After $48 \mathrm{~h}$ of growth on $\mathrm{NA}$ at 25 to $27^{\circ} \mathrm{C}$, the colonies were creamy white and flat, with irregular margins of 1 to $2 \mathrm{~mm}$ in diameter. On NSA, the colonies were levaniform and $2 \mathrm{~mm}$ in diameter.

Biochemical, physiological, and nutritional tests. All strains produced a fluorescent pigment on medium B of King et al. (11), were obligate aerobic, and did not accumulate poly- $\beta$-hydroxybutyrate. They were negative for oxidase, potato soft rot, and arginine dihydrolase and elicited a hypersensitive reaction on tobacco leaves. They belong to the LOPAT group Ia $(+---+)$, sensu Lelliott et al. (13). These features indicated that these strains from hazelnut could be classified to Pseudomonas syringae sensu lato (21) and they were not $P$. avellanae. Results of other biochemical and nutritional tests and the ice nucleation activity of the strains obtained from hazelnut in Piedmont and Sardinia showed the bacterium to be distinct from $P$. avellanae and other $P$. syringae pathovars (Table 2).

Presence of $\operatorname{syr} B$ gene. The $s y r B$ gene coding for the production of syringomycins was not amplified from any of the strains isolated in Piedmont and Sardinia from hazelnut cv. Tonda Gentile delle Langhe. Conversely, a 752-bp band was amplified from $P$. syringae pv. syringae NCPPB 3869 (positive control), indicating that the $\operatorname{syr} B$ gene was present.

$16 S$ rDNA gene sequencing. Sequencing of the entire $16 \mathrm{~S}$ rDNA gene of representative $P$. syringae strains obtained in Piedmont allowed us to compare their relatedness. The alignment of the sequences and the subsequent analysis highlighted differences in the base composition of the strains isolated in Piedmont.

TABLE 2. Ice nucleation activity and assimilation of selected carbon sources for discriminating Pseudomonas syringae pv. coryli from other related phytopathogenic Pseudomonas spp. and $P$. syringae pathovars ${ }^{\mathrm{a}}$

\begin{tabular}{|c|c|c|c|c|c|c|c|c|c|}
\hline \multirow[b]{2}{*}{ Character } & \multicolumn{2}{|c|}{ P. syringae pv. } & \multirow[b]{2}{*}{ P. avellanae } & \multicolumn{5}{|c|}{ P. syringae $\mathrm{pv}$. } & \multirow[b]{2}{*}{ P. coronafaciens } \\
\hline & coryli & syringae & & phaseolicola & morsprunorum & tomato & persicae & helianthi & \\
\hline Ice nucleation & $\mathrm{V}$ & + & - & $\mathrm{V}$ & - & - & + & ND & + \\
\hline Levan & + & + & + & $\mathrm{V}$ & + & + & + & + & + \\
\hline D-Mannitol & + & + & + & - & + & + & + & + & + \\
\hline Adonitol & - & + & - & - & - & - & - & - & - \\
\hline Inositol & + & + & + & - & + & + & - & + & + \\
\hline $\mathrm{L}(+)$ tartrate & - & - & - & - & + & - & - & + & + \\
\hline $\mathrm{D}(-)$ tartrate & - & V & - & - & - & + & - & $\mathrm{V}$ & - \\
\hline L-Lactate & - & + & - & - & - & $\mathrm{V}$ & - & - & - \\
\hline Gelatin liquefaction & - & + & - & - & - & + & ND & - & - \\
\hline Arbutin hydrolysis & + & + & - & - & - & + & ND & - & ND \\
\hline Aesculin hydrolysis & + & + & - & - & V & + & ND & - & ND \\
\hline
\end{tabular}

${ }^{\mathrm{a}} \mathrm{V}=$ variable: between 21 and $79 \%$ of strains positive; $\mathrm{ND}=$ not determined.

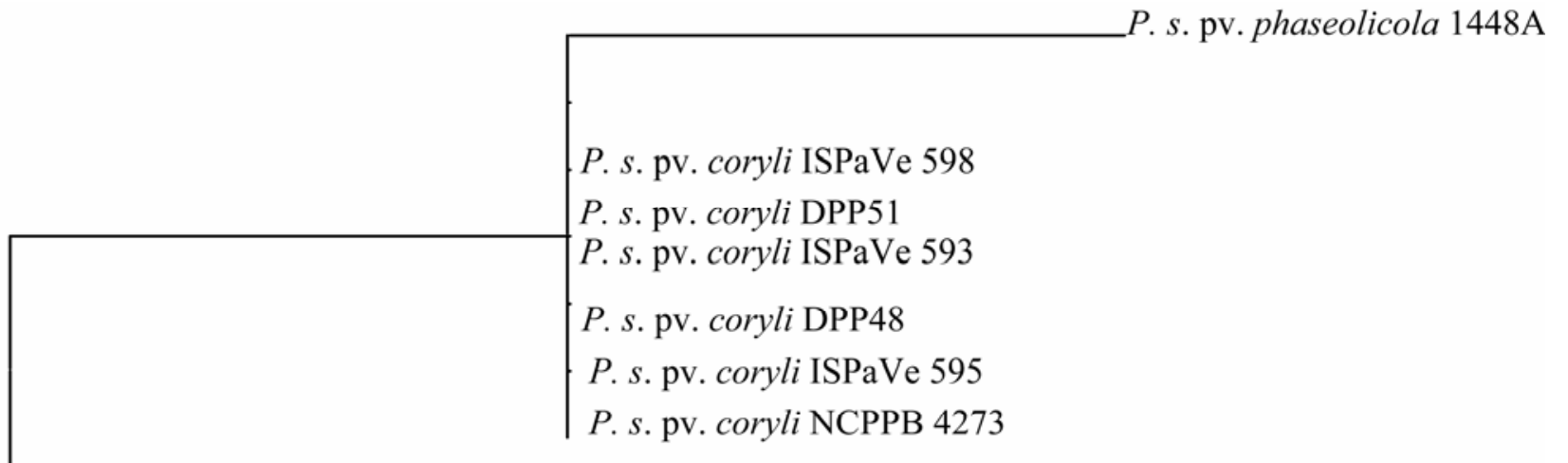

P. avellanae NCPPB 3873

0.001

Fig. 1. Pseudomonas syringae pv. coryli, $P$. syringae pv. phaseolicola, and $P$. avellanae partial $16 \mathrm{~S}$ rDNA sequence-derived neighbor-joining (NJ) phylogenetic tree. The NJ method was used to construct a tree from Kimura's two parameters estimated distances. Horizontal distances are proportional to phylogenetic distances expressed in substitutions per 100 sites; the scale bar represents the number of substitutions in each sequence. Vertical separations are for clarity only. 
ISPaVe 592 (NCPPB 4273) (GenBank accession AJ889841) showed, at position 1,000 of the gene, an adenine, whereas ISPaVe 595 and 598 have a guanine. P. avellanae BPIC 714 (GenBank accession AJ889838) and ISF 2059 (GenBank accession AJ889839) have identical sequences. In all, 13 bases resulted that were different between $P$. syringae pv. coryli NCPPB 4273 and the two $P$. avellanae strains. Major differences were found in positions 436 to 438 ( $P$. syringae pv. coryli showed GAT, whereas $P$. avellanae ATC), 1,070 to 1,072 (P. syringae pv. coryli CTT and $P$. avellanae TCC), and 1,084 to 1,087 (P. syringae pv. coryli TTG and $P$. avellanae GGA). The data confirmed that the $P$. syringae strains obtained from Tonda Gentile delle Langhe in Piedmont and Sardinia were different from $P$. avellanae strains isolated in Greece and Italy.

Partial 16S rDNA sequencing. To analyze a wider range of strains, a 448-bp section of the 16S rDNA genes (position 409 to 856) was amplified and sequenced from strains ISPaVe 592 (NCPPB 4273), 593, 595, DPP 48, and 51 as well as P. avellanae ISPaVe 011 and $P$. syringae pv. phaseolicola 1448A. A Clustal W alignment of the sequences revealed nucleotide substitutions for some of the sequences; most notably, a thymine/cytosine polymorphism was observed at position 326 of the 448-bp fragment for ISPaVe 592 and 593 genes. The base at this position could not be determined by sequencing the PCR amplification products, but it was resolved after cloning the PCR products and sequencing from the vector. Four clones containing the ISPaVe 592 gene and three clones containing the ISPaVe 593 gene were sequenced. Three of the four ISPaVe 592 clones revealed a thymine at position 326, whereas the fourth was a cytosine. Of the three ISPaVe 593 clones, two contained a thymine and the other a cytosine. An $\mathrm{NJ}$ tree based on this partial sequencing clearly separated $P$. avellanae from all the other strains obtained in Piedmont and Sardinia from hazelnut (Fig. 1).

Sequencing of $\boldsymbol{h r p L}$ gene. The full-length $h r p L$ gene was amplified and aligned from the representative $P$. syringae strains isolated from cv. Tonda Gentile delle Langhe in Piedmont and Sardinia ISPaVe 592 (NCPPB 4273), ISPaVe 598, and DPP 51. Conversely, primers $h r p L 7$ and 8 were not able to amplify the full length of $h r p L$ gene from $P$. avellanae strains. Molecular relationships between full-length $h r p L$ sequences or their deduced amino acid sequences showed that the strains obtained from hazelnut $\mathrm{cv}$. Tonda Gentile delle Langhe grouped in a single cluster (data not shown). These strains grouped in the same cluster in three lineages, each comprising two strains: ISPaVe 598 and 595; ISPaVe 593 and 592 (NCPPB 4273); and DPP 48 and 51. When compared with each other, the $h r p L$ sequences of each lineage shared a 99 to $100 \%$ homology. The strains belonging to different lineages showed a quite high homology of 94 to $98 \%$. PCR amplification of the partial hrpL gene gave rise to the expected fragment of $\approx 290$ bp from Tonda Gentile delle Langhe strains (NCPPB 4273, 598, and DPP51) and on P. avellanae strains (ISPaVe 011 and BPIC Fl13). Clustal W alignment of this partial hrpL sequence showed 22 base substitutions between the strains of Piedmont and Sardinia. Among them, 20 substitutions were silent and only 2 were not silent. Molecular relationships between these partial $h r p L$ sequences or their deduced amino acid sequences and the GenBank databank homologs of $P$. syringae pv. phaseolicola, $P$. syringae pv. tomato, and $P$. syringae pv. syringae are shown in the NJ tree (Fig. 2). The strains from hazelnut isolated in Piedmont and Sardinia grouped together in a single cluster with $P$. syringae pv. syringae $61 \mathrm{hrpL}$ lineage but independent of the $P$. syringae pv. phaseolicola and $P$. avellanae lineages.

Repetitive-sequence-based PCR genomic fingerprinting. The variability within the strains isolated in Piedmont and Sardinia and the relationship with other phytopathogenic pseudomonads also was assessed by using repetitive-sequence PCR with ERIC and BOX primer sets. Reproducible DNA fingerprints were generated from total DNA of all strains listed in Table 1. Both ERIC and BOX primers allowed differentiation of the strains from Piedmont and Sardinia from all the other pseudomonads. DNA polymorphism was evident in the region between 200 and 1,600. From the total pattern obtained, 21 BOX-PCR bands and 18 ERIC-PCR bands were used for composing a binary matrix, and a dendrogram obtained with UPGMA and the Dice's coefficients using ERIC primer is shown in the Figure 3. The hazelnut $P$. syringae isolates clustered separately from all the other

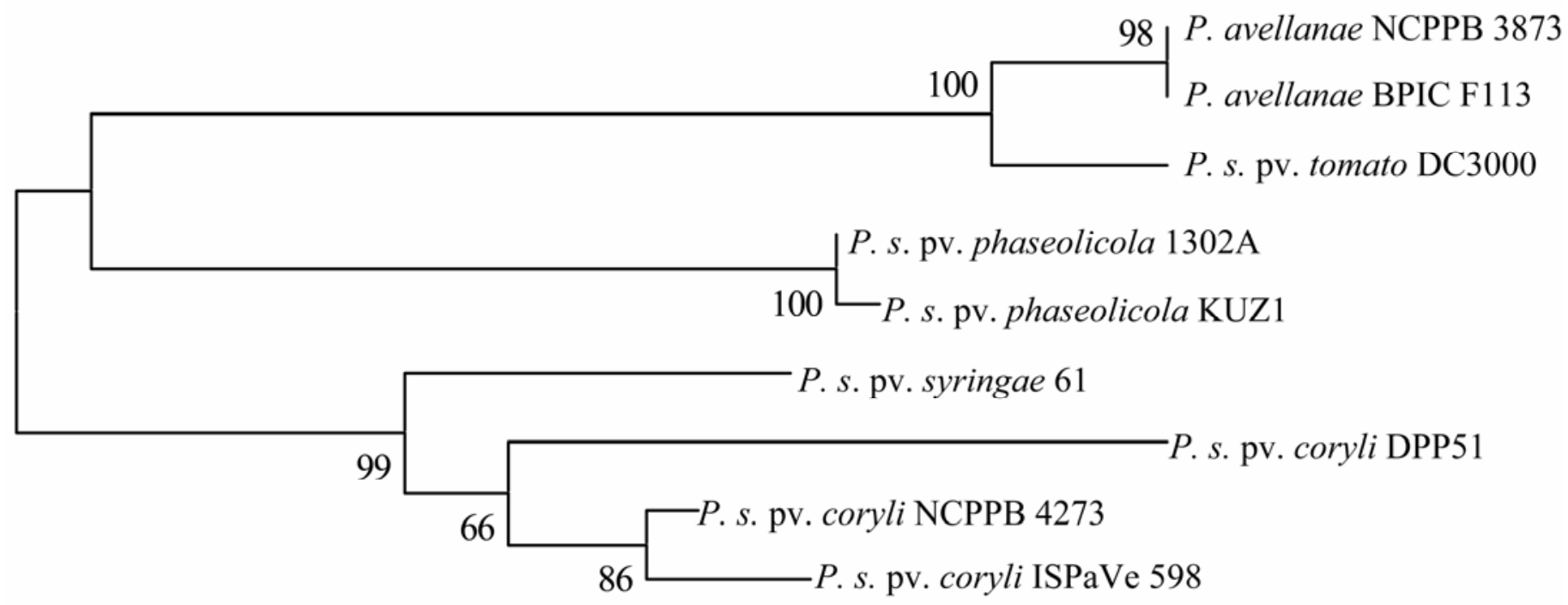

0.02

Fig. 2. Partial hrpL DNA sequences-derived neighbor-joining (NJ) phylogenetic tree of Pseudomonas syringae pv. coryli, P. avellanae, and the GenBank $P$. syringae pv. phaseolicola, $P$. syringae pv. tomato, and P. syringae pv. syringae database homologs. The NJ method was used to construct a tree from Kimura's two parameters estimated distances. Horizontal distances are proportional to phylogenetic distances expressed in substitutions per 100 sites. The scale bar represents the numbers of substitutions in each sequence. The significance of internal branches of NJ phylogenetic tree was assessed by applying the NJ algorithm to 1,000 bootstrap replicates. The numbers refer to bootstrap values. Accession numbers of the $P$. syringae database homologs are reported in the text. 
pseudomonads included in the comparison and showed a closer relationship with $P$. syringae pv. persicae and $P$. syringae pv. tomato but clearly were separated from $P$. avellanae and $P$. syringae pv. syringae. Variability existed within the strains, although the overall similarity was high $(95 \%)$.

FAME analysis. The comparison of FAME, performed with 28 $P$. avellanae and 33 strains obtained from hazelnut orchards of Piedmont and Sardinia using multidimensional principal component analysis, revealed two discrete clusters. Cluster I comprised

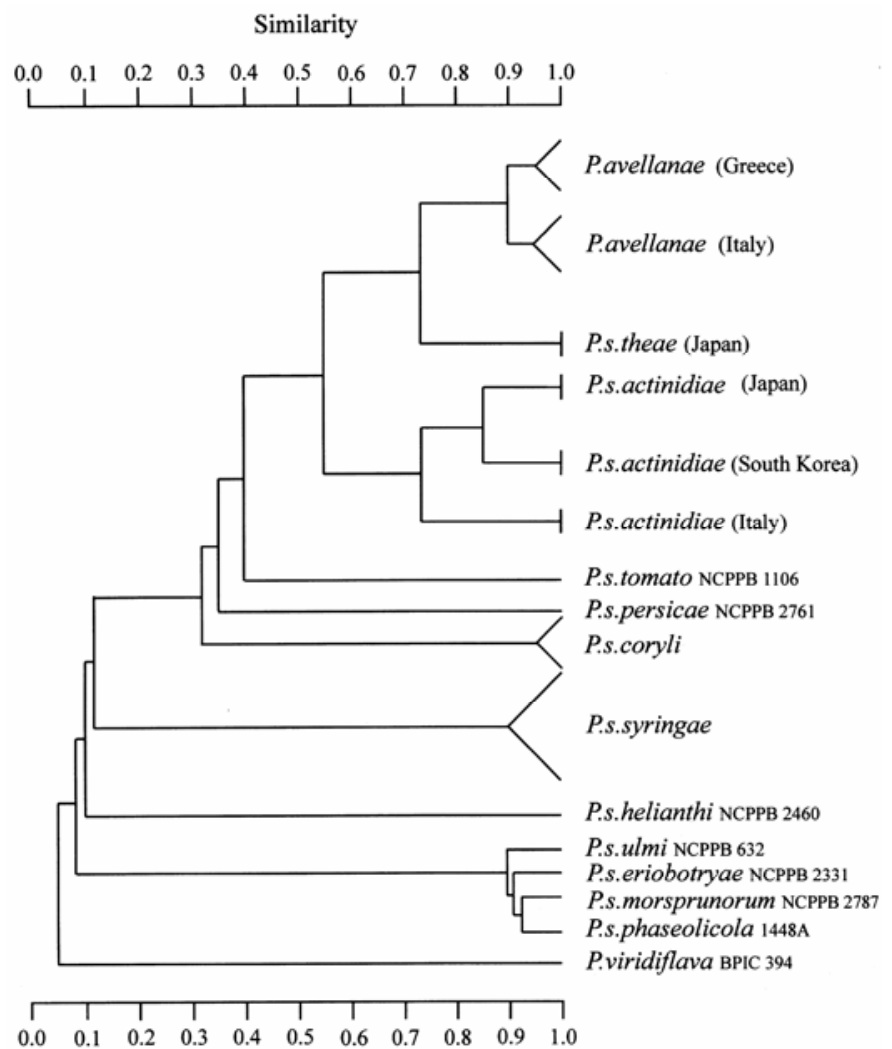

Fig. 3. Dendrogram obtained by unweighted pair group method with arithmetic means analysis using Dice's coefficients and ERIC polymerase chain reaction fingerprinting patterns from Pseudomonas syringae pv. coryli and other phytopathogenic pseudomonads. all strains isolated in Piedmont and Sardinia from cv. Tonda Gentile delle Langhe, whereas cluster II included $P$. avellanae strains isolated either in Greece or Italy (Fig. 4). The key fatty acids that differentiated $P$. avellanae from the strains isolated in Piedmont are given in Table 3. They differed markedly in the amount of the fatty acids 16:0, 18:0, 17:0 iso, 16:1w7c, 18:1w7c, 17:0 cyclo, 19:0 cyclo w8c, and 19 cyclo w10c. The fatty acid 17:0 iso was detected only in the strains isolated in Piedmont and Sardinia. When compared with other phytopathogenic pseudomonads, such strains also clustered separately from all the other taxa tested and clearly were different from $P$. syringae pv. syringae (Fig. 5).

Pathogenicity and host range tests. All strains induced the hypersensitive reaction in tobacco leaves. All strains tested were pathogenic to hazelnut cv. Tonda Gentile delle Langhe and, to a lesser extent, to hazelnut cv. Tonda Gentile Romana. Seven months after inoculation, small cankers were observed around the leaf scars on plants inoculated in autumn. On the shoots inoculated in spring, a twig dieback was observed 10 to 14 days after

TABLE 3. Whole-cell fatty acids found in 33 strains of Pseudomonas syringae pv. coryli and 26 strains of P. avellanae strains ${ }^{\mathrm{a}}$

\begin{tabular}{lcc}
\hline & \multicolumn{2}{c}{ Mean percent and standard deviation for strains of } \\
\cline { 2 - 3 } Fatty acid & P. avellanae & P. syringae pv. coryli \\
\hline Saturated & $0.4 \pm 0.3$ & $0.2 \pm 0.1$ \\
14:0 & $0.2 \pm 0.3$ & $0.2 \pm 0.1$ \\
$15: 0$ & $\mathbf{3 2 . 8} \pm 1.5$ & $\mathbf{2 7 . 5} \pm 1.7$ \\
$\mathbf{1 6 : 0}$ & $0.3 \pm 0.5$ & $0.4 \pm 0.1$ \\
$17: 0$ & $\mathbf{0 . 7} \pm 0.4$ & $\mathbf{1 . 2} \pm 0.2$ \\
18:0 & & \\
Saturated branched & $\mathbf{0}$ & $\mathbf{0 . 4} \pm 0.2$ \\
17:0 iso & & \\
Unsaturated & $\mathbf{4 3 . 3} \pm 0.9$ & $\mathbf{3 3 . 1} \pm 2.5$ \\
16:1 w7c & $\mathbf{8 . 2} \pm 2.1$ & $\mathbf{1 5 . 1} \pm 1.3$ \\
18:1 w7c & & \\
Hydroxy & $2.6 \pm 0.2$ & $2.7 \pm 0.2$ \\
10:0 3OH & $3.0 \pm 0.2$ & $3.0 \pm 0.1$ \\
12:0 2OH & $3.9 \pm 0.2$ & $4.4 \pm 0.2$ \\
12:0 3OH & & \\
Cyclo & $\mathbf{0}$ & $\mathbf{4 . 8} \pm 2.6$ \\
17:0 cyclo & $\mathbf{0}$ & $\mathbf{0 . 2} \pm 0.2$ \\
19:0 cyclo w8c & $\mathbf{0 . 3} \pm 0.3$ & $\mathbf{1 . 4} \pm 0.5$ \\
19:0 cyclo w10c &
\end{tabular}

${ }^{a}$ Discriminative acids are in bold. Only fatty acids with more than $0.2 \%$ and present in $50 \%$ or more of the strains tested are mentioned.

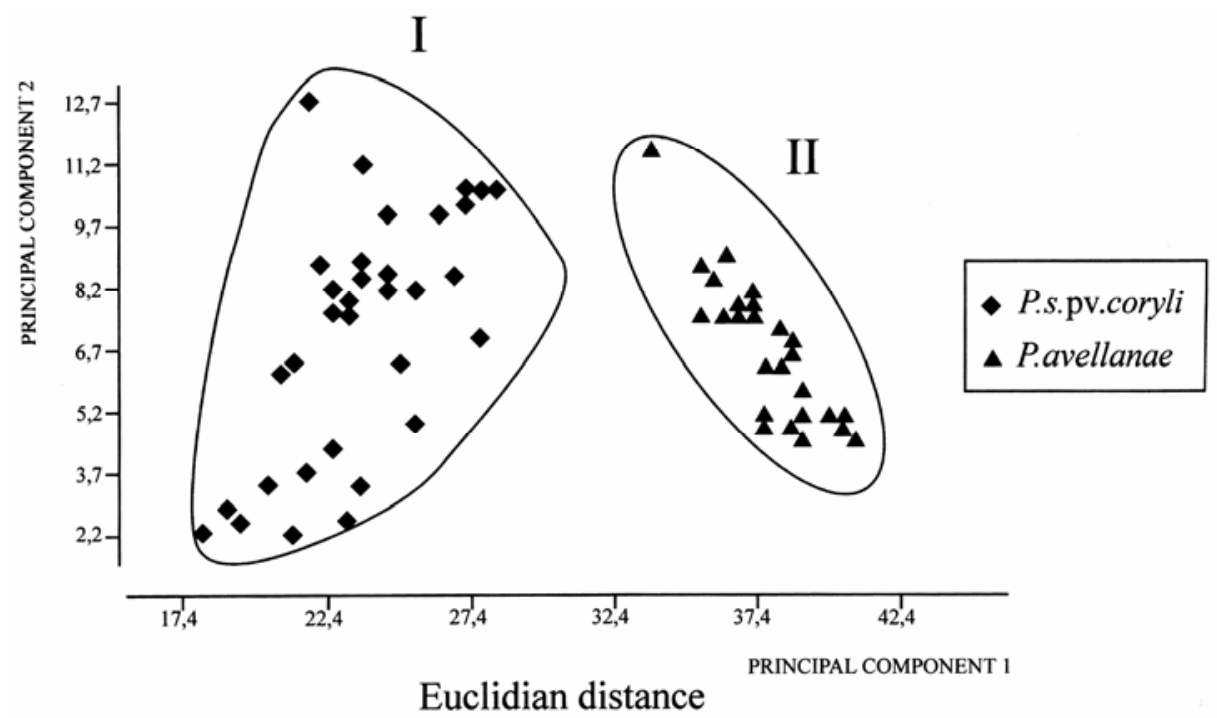

Fig. 4. Two-dimensional plot of principal component analysis of whole-cell fatty acids of 33 Pseudomonas syringae pv. coryli (cluster I) and 26 P. avellanae (cluster II) strains. 
inoculation and, occasionally, the infection reached the branch. On cv. Tonda Gentile Romana, the infection never reached the branches. Reisolations from symptomatic plants yielded bacterial colonies on NA and NSA that were identical to those used for the inoculations and yielded the same responses and fingerprinting to the LOPAT tests and repetitive-sequence PCR profiles. Pear shoots and, to a lesser extent, apricot and peach shoots and lemon fruit showed a light-brownish, nonenlarging area surrounding the inoculation site. On pepper and tomato plants, a small necrotic nonenlarging area surrounding the inoculation site was observed 4 days after inoculation. Lilac and apple shoots as well as the control plants did not show symptoms. On lemon fruit, only $P$. syringae pv. syringae NCPPB 3869 caused extensive necrotic lesions at the inoculation site. On bean pods, all strains incited necrotic, brownish lesions surrounding the inoculation site after 4 to 6 days, similar to a hypersensitivity reaction, whereas $P$. syringae pv. phaseolicola 1448A caused a water-soaked lesion surrounding the inoculation site. No symptoms were observed on lemon fruit and bean pods used as controls. Therefore, in our artificial inoculation studies, the pathogen was able to incite symptoms in hazelnut similar to those observed in hazelnut orchards, as well as very mild symptoms on some other plant species.

\section{DISCUSSION}

We have characterized a bacterial pathogen of hazelnut cv. Tonda Gentile delle Langhe that is distinct from other pathogenic bacteria described, and we propose to name the new pathovar $P$. syringae pv. coryli. The $P$. syringae pv. coryli strains are clearly distinct from $P$. avellanae, $P$. syringae pathovars, and $P$. syringae pv. syringae strains isolated from hazelnut orchards in the same areas (31). The sequencing of a 448-bp internal variable region of the 16S gene was useful for strain differentiation (22) but did not reveal any difference among the five strains tested. However, the sequencing of the entire 16S rDNA gene identified a single base difference at position 1,000 among three of the $P$. syringae pv. coryli strains examined. Small sequence differences within strains of a pathovar already have been observed $(20,26)$. Previously, amplified rDNA ribosomal analysis (ARDRA) made it possible to distinguish $P$. avellanae from $P$. syringae pv. actinidiae and $P$. syringae pv. theae (30). All strains appeared biochemically and nutritionally uniform and some tests were able to differentiate them from other $P$. syringae pathovars. In addition, fatty acids analysis enabled their rapid identification. Pathogenicity and host range tests indicated that the $P$. syringae pv. coryli strains caused severe symptoms only on Corylus avellana cv. Tonda Gentile delle Langhe.

The gene $h r p L$ codes for a putative sigma factor that belongs to the sigma-70-type sigma-factor family $(16,36)$ and is required for the expression of the $h r p$ gene cluster essential for both pathogenicity and induction of the hypersensitivity reaction in tobacco leaves. This gene is considered a good candidate for inferring phylogenetic relationship between phytopathogenic bacteria and it has been used to investigate genetic relationships of $P$. syringae spp. $(2,19,27)$. The partial sequencing of the hrpL gene differentiated three lineages in $P$. syringae pv. coryli and the strains isolated in Piedmont appeared slightly different from those obtained in Sardinia. Also, repetitive-sequence PCR allowed us to distinguish the strains isolated in Piedmont from those obtained from Sardinia, thus confirming the usefulness of this technique for strain differentiation (18). Such strain differences could represent an adaptation of the pathogen to a new environment. In fact, cv. Tonda Gentile delle Langhe was introduced to Sardinia only during the 1970s, whereas it has been cultivated in Piedmont since ancient times. Moreover, $P$. syringae pv. coryli incites more severe damage in Sardinia, where hazelnut is cultivated in acidic soils (4), whereas Piedmont soils are neutral or slightly basic. A greater susceptibility of hazelnut grown on acidic soils toward bacterial pathogens already has been observed for $P$. avellanae (29). It is interesting to note that, on hazelnut in Italy, three different pathogenic pseudomonads cause yield losses, with $P$. avellanae inciting the most severe epidemics only in central Italy, and $P$. syringae pv. syringae appearing present in all areas of $C$. avellana cultivation. It is necessary to determine whether $P$. syringae pv. coryli is restricted only to cv. Tonda Gentile delle Langhe or if it also colonizes other hazelnut germ plasm to investigate potentially resistant cultivars of hazelnut..

Description of $\boldsymbol{P}$. syringae pv. coryli, pv. nov. $P$. syringae pv. coryli (adjective from Corylus, the genus name of the host) cells are gram negative and motile, with one to three polar flagella and obligate aerobes with oxidative metabolism of glucose. On nutrient agar, it produces creamy white colonies, flat with irregular margins, 1 to $2 \mathrm{~mm}$ in diameter after $48 \mathrm{~h}$ of growth at 25 to $27^{\circ} \mathrm{C}$. The bacterium produces slight green fluorescent pigments on medium B of King et al. (11). The colonies are levan positive, oxidase negative, nonpectinolytic, and arginine dihydrolase negative, and give a hypersensitivity reaction on tobacco leaves: LOPAT Ia $(+---+)$ of Lelliott et al. (13). P. syringae pv. coryli hydrolyses arbutin and aesculin and produces tyrosinase. It is negative for nitrate reduction, lypolisis of Tween 80, and starch hydrolysis. It tolerates up to $0.1 \%$ of triphenyltetrazolium chloride and did not accumulate poly- $\beta$-hydroxybutyrate. The maximum temperature of growth is $35^{\circ} \mathrm{C}$. It shows a moderate ice nucleation activity $\left(\approx 80 \%\right.$ of strains are positive at $\left.-5^{\circ} \mathrm{C}\right)$. Differential growth on the following carbon sources separate $P$. syringae pv. coryli from the other $P$. syringae pathovars and related bacteria: assimilation of D-mannitol, inositol, and D-sorbitol; and no assimilation of adonitol, erythritol, $\mathrm{L}(+)$ tartrate, $\mathrm{D}(-)$ tartrate, and L-lactate. The following fatty acids were found in P. syringae pv. coryli, with their mean percentage reported in parentheses: 16:0 (27.5), 18:0 (1.2), 17:0 iso (0.4), 16:1 w7c (33.1), 18:1 w7c (15.11), 17:0 cyclo (4.8), 19:0 cyclo w8c (0.2), and 19:0 cyclo w10c (1.4). Pathogenic strains of $P$. syringae pv. coryli cause a twig dieback to $C$. avellana cv. Tonda Gentile delle Langhe.

The pathovar type strain (pathotype strain) was deposited in the National Collection of Plant-Pathogenic Bacteria, CSL, York, UK, as NCPPB 4273 and in the Culture Collection of the Plant Pro-

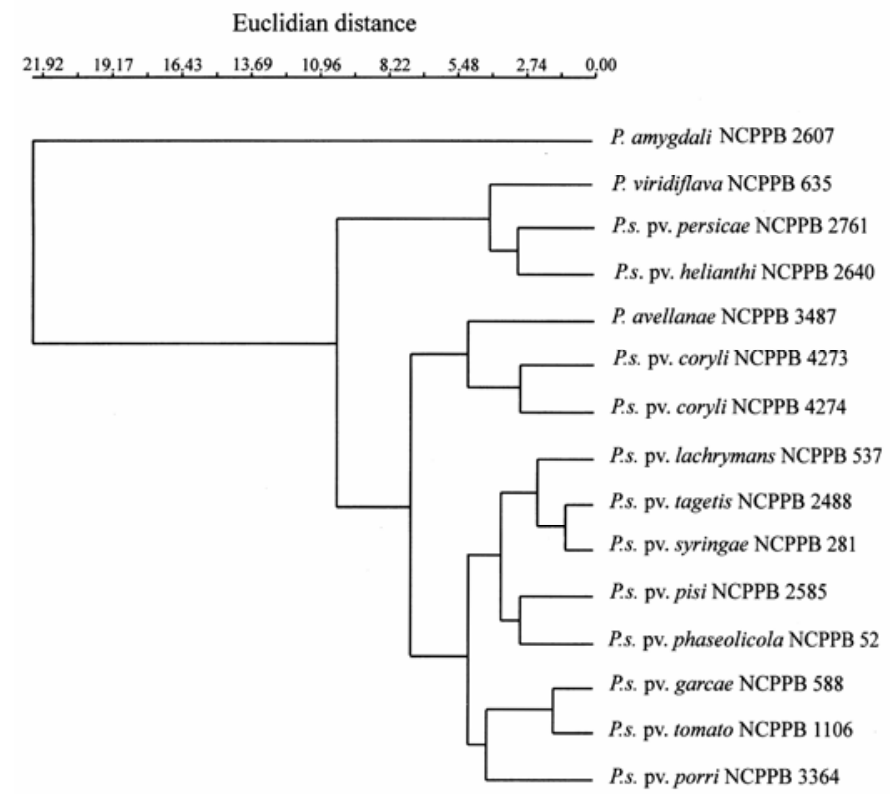

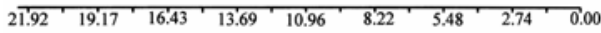

Fig. 5. Dendrogram of relationships between Pseudomonas syringae pv. coryli and other phytopathogenic pseudomonads based on fatty acid methyl esters analysis. 
tection Service, Wageningen, The Netherlands as PD 3478. The pathovar type-strain also is maintained in the culture Collections of the Istituto Sperimentale per la Patologia Vegetale and Istituto Sperimentale per la Frutticoltura, Roma, Italy, as ISPaVe 592.

\section{ACKNOWLEDGMENTS}

This work was financed partly by the project CO.RI.BIO: "Ricerche sul nocciolo finalizzate all'ottenimento di produzioni biologiche di qualità"; publication no. 1; and R. W. Jackson was funded by the Biotechnology and Biological Sciences Research Council, UK. We thank J. Heeney, Central Science Laboratory, York, UK and P. Gorkink-Smits, Plant Protection Service, Wageningen, The Netherlands for technical assistance.

\section{LITERATURE CITED}

1. Ausubel, F. M., Brent, R., Kinston, R. E., Moore, D. D., Smith, J. A., and Struhl, K. 1996. Current Protocols in Molecular Biology, vol. 1991-1996. Greene Publishing and Wiley-Interscience, New York.

2. Cournoyer, B., Arnold, D., Jackson, R. W., and Vivian, A. 1996. Phylogenetic evidence for a diversification of Pseudomonas syringae pv. pisi race 4 strains into two distinct lineages. Phytopathology 86:1051-1056.

3. Dice, L. R. 1945. Measures of the amount of ecologic association between species. Ecology 26:297-302.

4. Fiori, M., Cicconi, L., and Scortichini, M. 2003. Bacterial canker of hazelnut (Corylus avellana L.) in Sardinia: Occurrence of Pseudomonas syringae strains. Pages 617-625 in: Pseudomonas syringae and Related Pathogens. N. S. Iacobellis, A. Collmer, S. W. Hutcheson, J. W. Mansfield, C. E. Morris, J. Murillo, N. W. Schaad, D. E. Stead, G. Surico, and M. S. Ullrich, eds. Kluwer Academic Publishers, Dordrecht, The Netherlands.

5. Grifoni, A., Bazzicalupo, M., Di Serio, C., Fancelli, S., and Fani, R. 1995. Identification of Azospirillum strains by restriction fragment length polymorphism of the 16S rDNA and the histidine operon. FEMS Microbiol. Lett. 127:85-91.

6. Hedges, S. B. 1992. The number of replications needed for accurate estimation of the bootstrap $P$ value in phylogenetic studies. Mol. Biol. Evol. 9:366-369.

7. Higgins, D. G., and Sharp, P. M. 1988. CLUSTAL: A package for performing multiple sequence alignment on a microcomputer. Gene 73:237-244.

8. Janse, J. D. 1991. Pathovar discrimination within Pseudomonas syringae subsp. savastanoi using whole cell fatty acid and pathogenicity as criteria. Syst. Appl. Microbiol. 14:79-84.

9. Janse, J. D., Rossi, M. P., Angelucci, L., Scortichini, M., Derks, J. H. J., Akkermans, A. D. L., De Vrijer, R., and Psallidas, P. G. 1996. Reclassification of Pseudomonas syringae pv. avellanae as Pseudomonas avellanae (spec. nov), the bacterium causing canker of hazelnut (Corylus avellana L.). Syst. Appl. Microbiol. 19:589-595.

10. Kimura, M. 1980. A simple model for estimating evolutionary rates of base substitutions through comparative studies of nucleotide sequences. J. Mol. Evol. 16:111-120.

11. King, E. O., Ward, M. K., and Raney, D. E. 1954. Two simple media for the demonstration of pyocyanin and fluorescin. J. Clin. Lab. Med. 59:945952.

12. Kumar, S., Tamura, K., Jakobsen, I. B., and Nei, M. 2001. MEGA 2: Molecular Evolutionary Genetics Analysis software. Arizona State University, Tempe.

13. Lelliott, R. A., Billing, E., and Hayward, A. C. 1966. A determinative scheme for the fluorescent plant pathogenic Pseudomonas. J. Appl. Bacteriol. 29:470-489.

14. Lelliott, R. A., and Stead, D. E. 1987. Methods for the Diagnosis of Bacterial Diseases of Plants. Blackwell Scientific Publications for the British Society of Plant Pathology, Oxford.

15. Lindow, S. E. 1990. Bacterial ice-nucleation activity. Pages 428-434 in: Methods in Phytobacteriology. Z. Klement, K. Rudolph, and D. C. Sands, eds. Akademiai Kiado, Budapest.

16. Lonetto, M. A., Brown, K. L., Rudd, K. E., and Buttner, M. 1994. Analysis of the Streptomyces coelicolor sigE gene reveals the existence of a sub-family of eubacterial RNA polymerase sigma factor involved in the regulation of extracytoplasmatic functions. Proc. Natl. Acad. Sci. USA 91:7573-7577.

17. Loreti, S., Gallelli, A., Jackson, R. W., Butcher, D., Arnold, D., and Vivian, A. 2003. Characterization of effector genes of pseudomonads causing disease of hazelnut. Pages 393-398 in: Pseudomonas syringae and Related Pathogens. N. S. Iacobellis, A. Collmer, S. W. Hutcheson, J. W. Mansfield, C. E. Morris, J. Murillo, N. W. Schaad, D. E. Stead, G. Surico, and M. S. Ullrich, eds. Kluwer Academic Publishers, Dordrecht, The Netherlands.

18. Louws, F. J., Fullbright, D. W., Stephens, C. T., and De Bruijn, F. J. 1994. Specific genomic fingerprinting of phytopathogenic Xanthomonas and Pseudomonas pathovars and strains generated with repetitive sequence and PCR. Appl. Environ. Microbiol. 60:2286-2295.

19. Manceau, C., and Brin, C. 2003. Pathovars of Pseudomonas syringae are structured in genetic populations allowing the selection of specific markers for their detection in plant samples. Pages 503-511 in: Pseudomonas syringae and Related Pathogens. N. S. Iacobellis, A. Collmer, S. W. Hutcheson, J. W. Mansfield, C. E. Morris, J. Murillo, N. W. Schaad, D. E. Stead, G. Surico, and M. S. Ullrich, eds. Kluwer Academic Publishers, Dordrecht, The Netherlands.

20. Ménard, M., Sutra, L., Luisetti, J., Prunier, J.-P., and Gardan, L. 2003. Pseudomonas syringae pv. avii (pv. nov.), the causal agent of bacterial canker of wild cherries (Prunus avium L.) in France. Eur. J. Plant Pathol. 109:565-576.

21. Palleroni, N. J. 1984. Genus Pseudomonas. Pages 141-199 in: Bergey's Manual of Systematic Bacteriology, Vol. I. N. R. Krieg and J. G. Holt, eds. Williams and Wilkins, Baltimore, MD.

22. Preston, G. M., Bertrand, N., and Rainey, P. B. 2001. Type III secretion in plant growth-promoting Pseudomonas fluorescens SBW25. Mol. Microbiol. 41:999-1014.

23. Psallidas, P. G. 1987. The problem of bacterial canker of hazelnut in Greece caused by Pseudomonas syringae pv. avellanae. Bull. OEPP (Organ. Eur. Mediterr. Prot. Plant)/EPPO (Eur. Mediterr. Plant Prot. Organ.) Bull. 17:257-261.

24. Rohlf, F. J. 2000. NTSYS-PC. Numerical Taxonomy and Multivariate Analysis System, Version 2.11j.Exeter Software, Setauket, NY.

25. Saitou, N., and Nei, M. 1987. The neighbour-joining method: A new method for reconstructing phylogenetic trees. Mol. Biol. Evol. 4:406-425.

26. Samson, R., Shafik, H., Benjama, A., and Gardan, L. 1998. Description of the bacterium causing blight of leek as Pseudomonas syringae pv. porri (pv. nov.). Phytopathology 88:844-850.

27. Sawada, H., Suzuki, F., Matsuda, I., and Saitou, N. 1999. Phylogenetic analysis of Pseudomonas syringae pathovars suggests the horizontal gene transfers of $\arg K$ and the evolutionary stability of $h r p$ gene cluster. J. Mol. Evol. 49:627-644.

28. Schaad, N. W. 2001. Initial identification of common genera. Pages 1-16 in: Laboratory Guide for Identification of Plant Pathogenic Bacteria, 3rd ed. N. W. Schaad, J. B. Jones, and W. Chun, eds. The American Phytopathological Society, St. Paul, MN.

29. Scortichini, M. 2002. Bacterial canker and decline of European hazelnut. Plant Dis. 86:704-709.

30. Scortichini, M., Dettori, M. T., Angelucci, L., Rossi, M. P., and Marchesi, U. 2000. Genetic and pathogenic diversity of Pseudomonas avellanae strains isolated from Corylus avellana L. trees in north-west of Italy, and comparison with strains from other regions. Eur. J. Plant Pathol. 106:147154.

31. Scortichini, M., Marchesi, U., Rossi, M. P., and Di Prospero, P. 2002. Bacteria associated with hazelnut (Corylus avellana $\mathrm{L}$.) decline are of two groups: Pseudomonas avellanae and strains resembling $P$. syringae pv. syringae. Appl. Environ. Microbiol. 68:476-484.

32. Scortichini, M., Marchesi, U., Rossi, M. P., Janse, J. D., and Stead, D. E. 2003. The pseudomonads associated with bacterial canker and decline of hazelnut (Corylus avellana L.). Pages 583-593 in: Pseudomonas syringae and Related Pathogens. N. S. Iacobellis, A. Collmer, S. W. Hutcheson, J. W. Mansfield, C. E. Morris, J. Murillo, N. W. Schaad, D. E. Stead, G. Surico, and M. S. Ullrich, eds. Kluwer Academic Publishers, Dordrecht, The Netherlands.

33. Smith, J. J., Offord, L. C., Holderness, M., and Saddler, G. S. 1995 Genetic diversity of Burkholderia solanacearum (synonym: Pseudomonas solanacearum) race 3 in Kenya. Appl. Environ. Microbiol. 61:4263-4268.

34. Sorensen, K. N., Kim, K.-H., and Takemoto, J. Y. 1998. PCR detection of cyclic lipodepsinonapeptide-producing Pseudomonas syringae pv. syringae and similarity of strains. Appl. Environ. Microbiol. 64:226-230.

35. Stead, D. E. 1992. Grouping of plant pathogenic and some other Pseudomonas spp. by using cellular fatty acid profiles. Int. J. Syst. Bacteriol. 42:281-295.

36. Xiao, Y., Heu, S., Yi, L., and Hutcheson, S. W. 1994. Identification of a putative sigma factor and characterization of a multicomponent regulatory cascade controlling the expression of Pseudomonas syringae pv. syringae Pss61 hrp and hrmA genes. J. Bacteriol. 176:1025-1036. 